Journal of Applied Veterinary Sciences, 6 (3): 86 -93 (July, 2021).

ISSN: Online: 2090-3308, Print: 1687-4072

Journal homepage : https://javs.journals.ekb.eg

\title{
Current Evidence of Coryneform Bacteria on the Ocular Surface of Immunocompromised Cats
}

\author{
Yasmine M. Elmenshawy ${ }^{1}$, Khaled M. Ali2*, Ahmed Samir ${ }^{3}$ \\ ${ }^{1}$ Veterinarian,Veterinary Ophthalmology Clinic, Cairo, Egypt. \\ ${ }^{2}$ Department of Surgery, Anesthesiology and Radiology, Faculty of Veterinary Medicine, Cairo \\ University, Giza, 12211, Egypt. \\ ${ }^{3}$ Department of Microbiology, Faculty of Veterinary Medicine, Cairo University, Giza, 12211, Egypt. \\ *Corresponding Author, Khaled M. Ali, E-Mail: drkhaled_ali@cu.edu.eg; ORCID: https://orcid.org/0000-0003-0567-5472
}

\begin{abstract}
Monomicrobial and polymicrobial infections may occur on the cornea, conjunctiva and the eyelid of cats.Corynebacterium species are categorized as nonpathogenic bacteria that are regularly detected in the conjunctiva of healthy cats. It has been reported that Corynebacterium species have been shown to be potentially harmful in a variety of tissues including ocular tissues, skin, and mucous membranes. The purpose of the current study was to investigate the presence of Corynebacterium spp. on the ocular surface and its antimicrobial sensitivity and susceptibility pattern. We investigated Corynebacterium species on the ocular surface and reviewed various species of Corynebacterium in terms of their antimicrobial susceptibility and the underlying molecular resistance mechanisms. The risk for Corynebacterium-related ocular infections in cats with low immunity, such as poor nutrition, corneal epithelial damage due to trauma, corneal perforation, lagophthalmos, chronic incurable glaucoma, long-lasting corneal sequestrum, and long-term use of topical steroids have been identified. 64 cats (78 eyes) of different ages and both sexes with various ocular disorders were swabbed. Corynebacterium spp. represented $34.6 \%(n=27)$ of the collected sample and found to be susceptible to common antibiotics. Therefore, the use of antimicrobials for the treatment of ocular infections caused by Corynebacterium species should be a rational and sensible strategy along with provision of immunostimulants.
\end{abstract}

Keywords: Bacteria, Cat, Corynebacterium, Eye infections.

\section{Original Article:}

DOI:https://dx.doi.org/10.21608/javs.2 $\underline{021.81235 .1087}$

Received :18 June, 2021.

Accepted :15 July, 2021.

Published in July, 2021.

This is an open access article under the term of the Creative Commons Attribution 4.0 (CC-BY) International License . To view a copy of this license, visit:

http://creativecommons.org/licenses/by/4.0/

\section{INTRODUCTION}

Normal flora plays a vital role in maintaining healthy ocular epithelium throughout inhibition of apoptosis, regeneration processes and immunological control (Kielbowicz et al., 2015). The normal microbial flora is meant to prevent the invading microorganisms by depriving them of nutrients and secreting antimicrobial substances. It has been proven that long-term use of topical antibiotics and corticosteroids leads to depletion of normal ocular flora which contributes to overgrowth of pathogenic organisms, yeasts, and fungi (Ollivier, 2003). Nonpathogenic or mildly pathogenic bacteria can induce infection in immunocompromised hosts or manifest as co-infection (Gaskin, 1980).
Corynebacterium spp. can be found on ocular surface among other indigenous bacteria as Staphylococcus spp., Streptococcus spp., Bacillus spp., Pseudomonas spp., Moraxella spp., and Helicobacter spp. (Espinola and Lilenbaum, 1996; Buttner et al., 2018). In 1896, Lehmann and Neumann defined the genus Corynebacterium as a taxonomic group to comprise the bacterial rods that cause diphtheria (Das et al., 2016) Corynebacterium species are grampositive, catalase-positive, oxidase negative, nonspore-forming, non-motile, straight, or slightly curved rod-shaped bacteria (Davis, 1996). Their dimensions range from 2 to $6 \mathrm{~mm}$ in length and $0.5 \mathrm{~mm}$ in diameter. The microorganisms form a distinctive pattern that has been characterized as a 'I, N, T, V, W, Y', 'palisades,' or 'Chinese letters at 1000x magnification power.' They can also have a club 
shaped morphology at one or both ends; furthermore, they are pleomorphic throughout their life cycles and come in a variety of lengths, depending on the surrounding environment (Das et al., 2016). They are considered to have little pathogenicity; therefore, the isolation of Corynebacterium species from tissues with infection has been attributed to mishandling or contamination.

However, in immunocompromised patients, Corynebacterium have recently been shown to be potentially pathogenic when present on the ocular surface (Aoki et $\boldsymbol{a l}$., 2021). It has been detected in corneal ulcers in domestic cats, frequently as part of a mixed infection. Additionally, as a result of ocular trauma, Corynebacterium can cause blepharitis, orbital cellulitis, and abscesses especially in young cats (Ollivier, 2003). The presence of diverse Corynebacterium species on the ocular surface is not well understood in comparison to other organs, and the method by which they operate as harmful organisms is still also obscure (Aoki et al., 2021).

The purpose of the present study was to investigate the occurrence of Corynebacterium species in some ophthalmic diseases in cats and to study the antimicrobial susceptibility of such organism

\section{MATERIIALS AND METHODS}

\section{Sampling:}

This study was carried out on 64 client-owned cats (78 eyes) suffered from various ophthalmic diseases. The animals included in this study were those presented at the clinic of Surgery, Anesthesiology and Radiology Department, Faculty of Veterinary Medicine, Cairo University, and those admitted to a private veterinary ophthalmic clinic, Giza, Egypt, for evaluation of ophthalmic problems, in the period between December 2019 and January 2021.

Before inclusion, all cats were subjected to detailed ophthalmic examination (Ali and Hassan, 2020). Cats that showed signs of ocular infections presented as ocular discharges, redness, and blepharospasm were enrolled in the present study. All cats previously treated with antimicrobials were excluded from the study.

\section{Isolation and identification of bacterial pathogens:}

Sterile swabs from cornea and conjunctiva of the affected eye/s (Figure 1) of each cat were subjected to microbiological examination. Samples were inoculated into Cary and Blair transport media, and were delivered directly to the laboratory, incubated for 24 hours at $37^{\circ} \mathrm{C}$, then cultured on defibrinated $5 \%$ sheep blood agar media (Oxoid, Ltd., Hampshire, UK). All plates were incubated at $37^{\circ} \mathrm{C}$ for 24 hours. Isolated colonies were identified according to culture characteristics, bacterial films stained with Gram's technique, and catalase reaction (BD, Maryland, USA). Catalase-positive, Gram-positive, nonspore-forming bacilli arranged in pleomorphic arrangement were presumptively identified as Coryneform bacteria. Furthermore, all isolates were identified using the Biolog system (Biolog, Inc., Hayward, CA) and the API Coryne System (MO) and isolates were tested by the protocols recommended by the manufacturer.

\section{Antibacterial and susceptibility testing of the recovered isolates:}

The strains were tested for their antibiotic resistance patterns using the disk diffusion method. Steps of the test and interpretation were relying on the instructions of the Clinical and Laboratory Standards Institute. (CLSI, 2015)

\section{RESULTS}

The breeds included in the present study were Domestic Short-haired (DSH, $n=30)$, Persian $(n=25)$, Himalayan $(n=5)$, and Siamese $(n=4)$. The mean age $( \pm \mathrm{SD})$ at the initial presentation was $47.86( \pm 19.28)$ months (range, 4-96 months). There were 45 females (25 intact and 20 spayed) and 19 intact males. The mean $( \pm \mathrm{SD})$ duration of clinical signs prior to presentation was $12.44( \pm 7.23)$ days (range, 3-37 days).

Corynebacterium spp. were recovered from 27 cats (15; male and 12 ; female) out of the $78(34.6 \%)$ tested samples, 27 samples (14; left eye and 13; right eye) were collected from 16 domestic short hair cats (DSH), 8 Persian cats, 2 Siamese cats and 1 Himalayan cat. Table (1) summarizes the different types of affections in cats of different breeds, ages and sexes, and table (2) demonstrates the antimicrobial susceptibility pattern of the isolated Corynebacterium spp. Briefly, Corynebacterium spp. were further identified into $C$. propinicuum $(\mathrm{n}=10), C$. xerosis $(\mathrm{n}=5)$, C. striatum $(\mathrm{n}-5)$, Rhodococcus $\mathrm{spp} .(\mathrm{n}=4)$, and Actinomycis tunicens $(\mathrm{n}=3)$.

Moreover, Corynebacterium spp. were often found to be involved in corneal and conjunctival disorders, the sampled cases were keratoconjunctivitis $(n=9)$, ulcerative keratitis $(n=6)$, corneal perforation $(n=5)$, corneal abscess $(n=2)$, panophthalmitis $(n=3)$, corneal sequestration $(n=1)$, and glaucoma $(n=1)$. Fortunately, all Corynebacterium spp. isolates were susceptible to majority of the routinely used antibiotics. After Gram's staining all Corynebacterium spp appeared as Gram-positive non spore forming pleomorphic bacilli (Figure 2) and the isolated Actinomyces spp. were Gram-positive filamentous rods (Figure 3). 
Table 1: Different ocular affections and isolated Corynebacterium spp. from 27 cats enrolled in this study.

\begin{tabular}{|c|c|c|c|c|c|}
\hline \multirow{2}{*}{$\begin{array}{c}\text { Ocular } \\
\text { manifestations }\end{array}$} & \multicolumn{4}{|c|}{ Cases } & \multirow{2}{*}{$\begin{array}{l}\text { Bacterial } \\
\text { isolates }\end{array}$} \\
\hline & Breed & $\begin{array}{c}\text { Age } \\
\text { (months) }\end{array}$ & Sex & $\begin{array}{l}\text { Infected } \\
\text { eye }\end{array}$ & \\
\hline \multirow{9}{*}{$\begin{array}{l}\text { Keratoconjunctivitis } \\
\qquad(9 \text { cases })\end{array}$} & DSH & 12 & Male & OD & C. striatum \\
\hline & DSH & 24 & Male & OS & C. propinicuum \\
\hline & DSH & 54 & Female & OD & C. propinicuum \\
\hline & DSH & 36 & Female & OS & C. striatum \\
\hline & Persian & 18 & Female & OD & C.xerosis \\
\hline & DSH & 4 & Male & OD & C. propinicuum \\
\hline & DSH & 96 & Male & OS & C.xerosis \\
\hline & DSH & 36 & Female & OS & C. striatum \\
\hline & $\mathrm{DSH}$ & 6 & Female & OD & C. propinicuum \\
\hline \multirow{6}{*}{$\begin{array}{l}\text { Ulcerative keratitis } \\
\text { ( } 6 \text { cases })\end{array}$} & Siamese & 64 & Male & OS & C.xerosis \\
\hline & DSH & 48 & Female & OD & $\begin{array}{l}\text { Rhodococcus } \\
\text { spp. }\end{array}$ \\
\hline & DSH & 18 & Male & OS & C. propinicuum \\
\hline & Persian & 48 & Male & OD & C. striatum \\
\hline & Persian & 6 & Male & OS & C.xerosis \\
\hline & Persian & 6 & Female & OS & $\begin{array}{l}\text { Actinomycis } \\
\text { tunicens }\end{array}$ \\
\hline \multirow{5}{*}{$\begin{array}{l}\text { Corneal perforation } \\
\text { ( } 5 \text { cases })\end{array}$} & Persian & 24 & Male & OS & C. propinicuum \\
\hline & DSH & 4 & Female & OD & C. propinicuum \\
\hline & Himalayan & 24 & Female & OS & $\begin{array}{l}\text { Rhodococcus } \\
\text { spp. }\end{array}$ \\
\hline & Persian & 6 & Female & OD & $\begin{array}{l}\text { Rhodococcus } \\
\text { spp. }\end{array}$ \\
\hline & Persian & 12 & Male & OS & $\begin{array}{l}\text { Actinomycis } \\
\text { tunicens }\end{array}$ \\
\hline \multirow[t]{2}{*}{$\begin{array}{l}\text { Corneal abscess } \\
\quad(2 \text { cases })\end{array}$} & DSH & 3 & Female & OS & $\begin{array}{l}\text { Actinomycis } \\
\text { tunicens }\end{array}$ \\
\hline & Siamese & 72 & Male & OD & C. propinicuum \\
\hline \multirow{3}{*}{$\begin{array}{l}\text { Panophthalmitis } \\
\text { (3 cases) }\end{array}$} & DSH & 78 & Female & OD & C. striatum \\
\hline & DSH & 5 & Female & OD & C. xerosis \\
\hline & DSH & 4 & Male & OD & $\begin{array}{l}\text { Rhodococcus } \\
\text { spp. }\end{array}$ \\
\hline $\begin{array}{l}\text { Corneal sequestrum } \\
\text { ( } 1 \text { case })\end{array}$ & DSH & 5 & Female & OS & C. propinicuum \\
\hline $\begin{array}{c}\text { Glaucoma } \\
\text { (1 case })\end{array}$ & Persian & 8 & Female & OS & C. propinicuum \\
\hline
\end{tabular}

OD: Oculus Dexter, OS: Oculus Sinister 
Yasmine M. Elmenshawy et al.......

Table 2: Antimicrobial sensitivity pattern of Corynebacterium spp. in the present study

\begin{tabular}{|c|c|c|c|c|c|c|c|}
\hline $\begin{array}{l}\text { Antibiotic } \\
\text { Isolates }\end{array}$ & Chloramphenicol & Ciprofloxacin & Ofloxacin & Vancomycin & Moxifloxacin & Gatifloxacin & Cefazolin \\
\hline C. striatum & $\mathrm{S}$ & I & I & $S$ & $S$ & $\mathrm{~S}$ & $\mathrm{~S}$ \\
\hline C. propinicuum & $S$ & $\mathrm{I}$ & $S$ & $S$ & $S$ & $S$ & $S$ \\
\hline C. propinicuum & $\mathrm{S}$ & I & $\mathrm{S}$ & $S$ & $S$ & I & $\mathrm{S}$ \\
\hline C. striatum & $S$ & $S$ & $S$ & $\mathrm{~S}$ & $S$ & I & I \\
\hline C. xerosis & $\mathrm{S}$ & $S$ & $S$ & $S$ & $S$ & I & $S$ \\
\hline C. propinicuum & $S$ & $S$ & $S$ & $S$ & I & $S$ & $S$ \\
\hline C.xerosis & I & $S$ & $\mathrm{~S}$ & $S$ & I & I & $\mathrm{S}$ \\
\hline C. striatum & I & $S$ & $\mathrm{~S}$ & $S$ & $S$ & $\mathrm{~S}$ & I \\
\hline C. propinicuum & $S$ & $S$ & $S$ & $S$ & I & $S$ & $S$ \\
\hline C.xerosis & $\mathrm{S}$ & $S$ & $\mathrm{~S}$ & $S$ & I & I & $\mathrm{S}$ \\
\hline Rhodococcus spp. & $S$ & I & I & $S$ & $\mathrm{I}$ & $S$ & $S$ \\
\hline C. propinicuum & I & $S$ & $S$ & $S$ & $S$ & $S$ & $S$ \\
\hline C. striatum & $S$ & $S$ & $S$ & $S$ & $S$ & $S$ & I \\
\hline C. xerosis & I & $\mathrm{S}$ & $S$ & $S$ & $S$ & $S$ & $S$ \\
\hline $\begin{array}{l}\text { Actinomycis } \\
\text { tunicens }\end{array}$ & $S$ & $S$ & I & $S$ & I & $S$ & $\mathrm{~S}$ \\
\hline C. propinicuum & $\mathrm{S}$ & I & I & $S$ & $S$ & I & $S$ \\
\hline C. propinicuum & $S$ & I & $S$ & $S$ & $S$ & $\mathrm{~S}$ & I \\
\hline Rhodococcus spp. & $S$ & $S$ & $\mathrm{~S}$ & $S$ & $S$ & $S$ & I \\
\hline Rhodococcus spp. & I & $\mathrm{S}$ & $\mathrm{S}$ & S & I & $S$ & $S$ \\
\hline $\begin{array}{l}\text { Actinomycis } \\
\text { tunicens }\end{array}$ & I & $S$ & $\mathrm{~S}$ & $S$ & I & I & $S$ \\
\hline $\begin{array}{l}\text { Actinomycis } \\
\text { tunicens }\end{array}$ & $\mathrm{S}$ & $\mathrm{S}$ & $\mathrm{S}$ & $S$ & $S$ & $S$ & $S$ \\
\hline C. propinicuum & I & $S$ & I & I & $S$ & $S$ & $S$ \\
\hline C. striatum & $S$ & I & $S$ & $S$ & $S$ & I & $\mathrm{S}$ \\
\hline C.xerosis & $\mathrm{S}$ & $S$ & $S$ & $S$ & $S$ & $\mathrm{~S}$ & $\mathrm{~S}$ \\
\hline Rhodococcus spp. & $\mathrm{S}$ & $S$ & $S$ & $S$ & $\mathrm{I}$ & I & $\mathrm{S}$ \\
\hline C. propinicuum & $\mathrm{S}$ & $S$ & $\mathrm{~S}$ & $S$ & I & I & $S$ \\
\hline C. propinicuum & $S$ & I & $\mathrm{S}$ & S & $S$ & I & $\mathrm{S}$ \\
\hline
\end{tabular}

S: sensitive, I: intermediate 


\section{Current Evidence of Coryneform Bacteria.........}

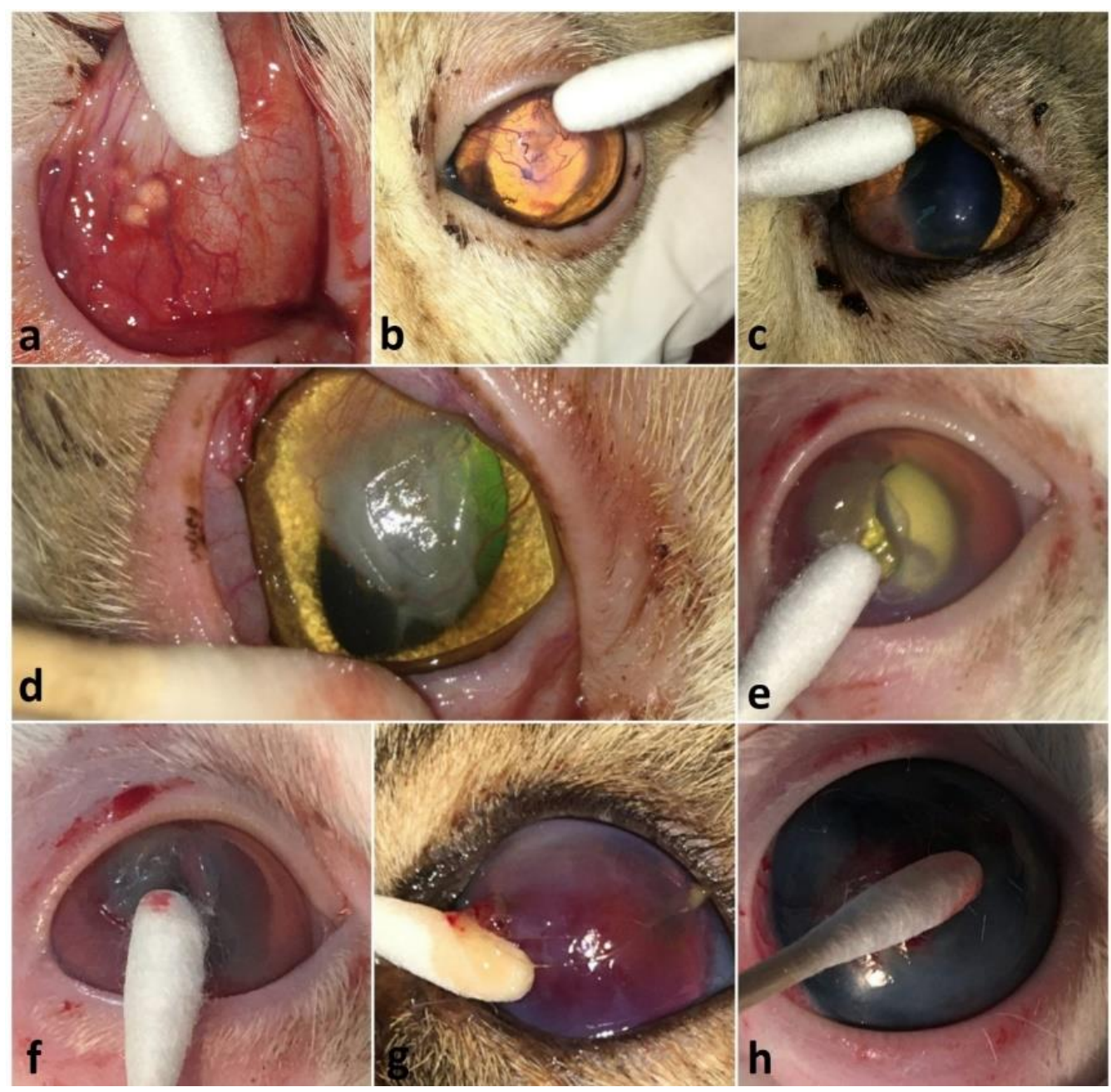

Fig. 1: Photographs showing the clinical presentation and sampling technique from cats with keratoconjunctivitis (a,b,c and d), corneal ulcers (e and f), corneal perforation and endophthalmitis ( $\mathrm{g}$ ) and chronic incurable glaucoma $(\mathrm{h})$.

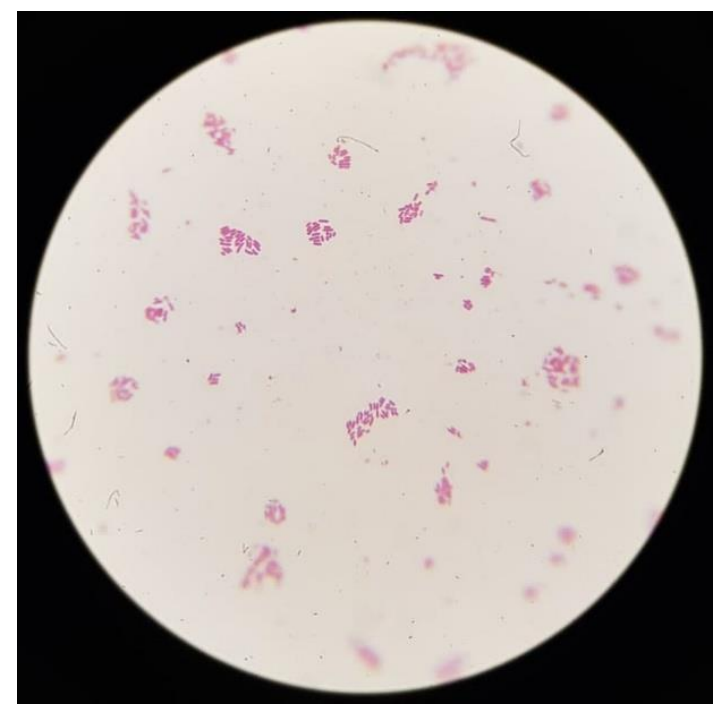

Fig. 2: Arrangement of Corynebacterium spp. by Gram's stain showing Gram-positive non spore forming pleomorphic bacilli (100x) (Vshaped, L-shaped, palisade and Chinese letter).

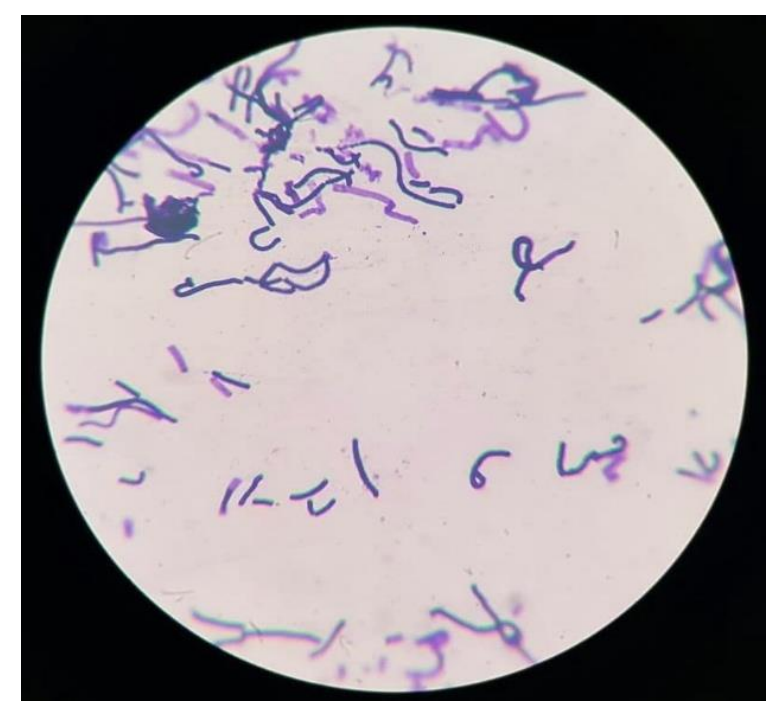

Fig. 3: Arrangement of Actinomyces spp. by Gram's stain showing Gram-positive filamentous rods $(100 \times)$ 


\section{DISCUSSION}

The ocular surface is composed of the corneal epithelium, the conjunctiva, Maibomian gland, the lacrimal system and eyelids, which is the body's most notably exposed mucous membrane. Moreover, since it is constantly in contact with the surroundings, it mostly represents an open apparatus that is bombarded by pathogenic and nonpathogenic microorganisms (Darden et al., 2019). This wide-open access is dependent on the eye's defense mechanism to discourage pathogenic microorganisms from colonizing the ocular surface.

The ocular surface is naturally inhabited by microorganisms that constitute its normal microflora. In different animal species, including horses (Andrew et al., 2003 and Johns et al., 2011), mules (Tamarzadeh and Araghi- Ooreh, 2014), donkeys (Foti et al., 2013), sheep (Bonelli et al., 2014), dogs (Prado et al., 2005), cats (Hussein, 218) and rabbits (Oriá et al., 2014). Bacterial population often isolated from healthy eyes is composed of gram-positive bacteria, although strains of methicillin-resistant to Staphylococcus (MRS) and gram negative strains, have also been identified (Santos et al., 2009; Johns et al., 2011; Mouney et al., 2013).

Some eye infections, however, can be caused by resident microorganisms, which become potentially pathogenic after their virulence is increased by external factors, such as trauma, stress, aging and reduction in commensal microbiota (Cogen $\boldsymbol{e t}$ al. 2008). Moreover, External ocular disease involving the conjunctiva and cornea in association with bacterial agents is considered to be a common problem in small animal practice. Conditions include bacterial conjunctivitis, kerato conjunctivitis sicca, dacrocystitis, bacterial keratitis presenting as corneal ulceration, and traumatic lesions. Previous investigations of the bacterial types associated with ocular surface disease in dogs have shown that Gram-positive isolates predominate and Gram-negatives such as Pseudomonas spp. and coliforms are isolated at a lower frequency (Gerding $\boldsymbol{e t}$ al., 1988).

Previous studies demonstrated that the most frequently isolated species of bacteria causing eye infections are Staphylococcus spp., Streptococcus spp., and Pseudomonas spp. in dogs (Tolar, et al., 2006) and Pseudomonas spp., Streptococcus spp., and Staphylococcus spp. in horses (Sauer et al., 2003) The most frequently isolated species of bacteria from the ocular surface of healthy cats were Staphylococcus spp.(Hussein 2018), Pseudomonas spp., Pasteurella spp., and beta-hemolytic Streptococcus spp. (Espinola and Lilenbaum, 1996).
Staphylococci andstreptococci accounted for $66 \%$ of the bacterial isolates in dogs and $80 \%$ of the isolates in cats and horses. The isolation rates of ocular surface bacteria and the percentages of negative cultures vary across studies (Tolar et al., 2006 and Hussein 2018).

In this study, we reported that $33 \%$ of the ocular affections induced by Corynebacterium spp. were Keratoconjunctivitis, 22\% were ulcerative Keratitis, $18 \%$ were perforated corneas, $7 \%$ were corneal abscesses, $11 \%$ were panophthalmitis, and $3 \%$ were corneal sequestration. Our findings are in agreement with the fact that eye's immunological shield is compromised by trauma or surgery, triggered by the opportunistic normal microbiota (Buttner et al., 2018 Goldreich et al., 2019; Das et al., 2015; Ollivier, 2003).

Since Corynebacterium spp. is typically identified as a commensal bacterium, defining them as a causal agent of eye infections is usually ruled out. However, most commensals have the ability to convert into pathogenic bacteria whenever the circumstances are appropriate that this bacterium may attach much easier to damaged tissues, keratitis, conjunctivitis, and corneal ulcers and serve as predisposing factors that contribute to the onset of infection. (Das el al., 2015, Ollivier, 2003). It has also been reported that during infection of the eye, Corynebacterium were engulphed by polymorphonuclear leucocytes which refers to their ability to induce an infection (Aoki et. al, 2021).Our results revealed also that Corynebacterial eye infections were found in immunosuppressed cats. According to our findings, Corynebacterium spp. represented $34.6 \%$ (27 out of 78) of the total collected samples, which is regarded a relatively high percentage in comparison with similar studies that obtained from cats suffered from keratitis in Ithaca (1.9\%) (Goldreich et al., 2019). and in Mosul (14.89\%) (Hussein, 2018).

The current study validated that antibiotic such as chloramphenicol, glycopeptides, cephalosporins, and fluoroquinolones are effective against Corynebacterial ocular affection in cats under investigation. Our findings were in concordance with previous studies that showed broad susceptibility patterns of Corynebacterium spp. recovered from cat eyes to different classes of antibiotics (Goldreich et al., 2019; Hussein, 2018; Ollivier, 2003).

\section{CONCLUSION}

Development of keratitis, conjunctivitis and other ocular infections in cats may be predisposed by the presence of Corynebacterium spp., which is commonly identified as a commensal bacterium, which 
may result in more serious eye diseases. The use of broad spectrum antibiotics in these cases were justified, and should be supported with antibiotic sensitivity test.

\section{Declaration of Conflicting Interests}

The authors revealed that there was no potential conflicts of interest.

\section{REFERENCES}

ALI, K.M. AND HASSAN, M.H., 2020.Visual outcome evaluation of complicated perforating corneal injuries after surgical repair in 45 cats. Turk $\mathrm{J}$ Vet Anim Sci., 44: 894-903. doi:10.3906/vet-2003-107.

ANDREW, S., ENGUYEN, A., JONES G.L. AND BROOKS D.E., 2003. Seasonal effects on the aerobic bacterial and fungal conjunctival flora of normal thoroughbred brood mares in Florida. Veterinary Ophthalmology, 6(1): 45-50, doi: 10.1046/j.1463-5224.2003.00265.x.

AOKI, T., KITAZAWA, K., DEGUCHI, H., AND SOTOZONO, C., 2021. Current Evidence for Corynebacterium on the Ocular Surface. Microorganisms. 27;9(2):254.

BONELLI, F. et al. 2014. Conjunctival bacterial and fungal flora in clinically normal sheep. Veterinary Record, 1(1):1-4. doi: 10.1136/vropen-2013-000017.

BUTTNER, J.N., SCHNEIDER, M., CSOKAI, J., MU“ LLER E, AND EULE, J.C. 2018. Microbiota of the conjunctival sac of 120 healthy cats. Vet Ophthalmol., 22(3):328-336.

CLINICAL AND LABORATORY STANDARD INSTITUTE. Methods for antimicrobial dilution and disk susceptibility testing of infrequently isolated or fastidious bacteria, $3^{\text {rd }}$ edition (M45). Wayne (PA): The Institute; 2015.

COGEN, A.L. et al. 2008. Skin microbiota: a source of disease or defense? British Journal of Dermatology, 158(3):442-455. doi: $10.1111 / \mathrm{j} .1365$ 2133.2008.08437.x.

DARDEN, J.E., SCOTT, E.M., ARNOLD, C., SCALLAN, E.M., SIMON, B.T., AND SUCHODOLSKI, J.S. 2019. Evaluation of the bacterial ocular surface microbiome in clinically normal cats before and after treatment with topical erythromycin. PLoS One., 11;14(10):e0223859.

DAS, S., RAO, A.S., SAHU, S.K., AND SHARMA, S., 2016. Corynebacterium spp. as causative agents of microbial keratitis. Br J Ophthalmol., 100(7):939943.

DAVIS, C.P., 1996. Normal flora. In Medical Microbiology, 4th edition.; University of Texas Medical Branch at Galveston: Galveston, TX, USA, .

ESPÍNOLA, M.B., AND LILENBAUM, W., 1996. Prevalence of bacteria in the conjunctival sac and on the eyelid margin of clinically normal cats. J Small Anim Pract.;37:364-366.

FOTI, M. FISICHELLA, V. AND GIACOPELLO C., 2013. Detection of methicillin-resistant Staphylococcus aureus (MRSA) in the microbial flora from the conjunctiva of healthy donkeys from Sicily (Italy). Veterinary Ophthalmology, 16(2): 89.
GASKIN, J.M., 1980. Microbiology of the canine and feline eye. Vet Clin North Am Small Anim Pract., 10(2): 303-316.

GERDING, P.A., McLAUGHLIN, S.A. AND TROOP, M.W., 1988. Pathogenic bacteria and fungi associated with external diseases in dogs: 131 cases (1981-1986). J. Am. Vet. Med. Assoc., 193:242-244.

GOLDREICH, J.E., FRANKLIN-GUILD, R.J. AND LEDBETTER, E.C., 2019. Feline bacterial keratitis: Clinical features, bacterial isolates, and in vitro antimicrobial susceptibility patterns. Vet Ophthalmol, 23(1):90-96 https://doi: 10.1111/vop.12693.

HUSSEIN, S. A., 2018. Bacterial Eye Infection of Cats. Multi-Knowledge Electronic Comprehensive Journal for Education And Science Publications (MECSJ), (11): 611-622.

JOHNS, I.C. BAXTER, K., BOOLER, H., HICKS, C. AND MENZIES-GOW N., 2011. Conjunctival bacterial and fungal flora in healthy horses in the UK. Veterinary Ophthalmology, 14(3): 195-199, doi: 10.1111/j.1463-5224.2010.00867.x.

KIEŁBOWICZ, Z., PLONECZKA-JANECZKO, K., BANIA, J., BIEROWIEC, K. AND KIELBOWICZ, M., 2015. Characteristics of the bacterial flora in the conjunctival sac of cats from Poland. J Small Anim Pract, 56(3):203-206.

MOUNEY, M.C. STILES, J., TOWNSEND, W.M., GUPTILL, L. AND WEESE J.S., 2015. Prevalence of methicillin-resistant Staphylococcus spp. in the conjunctival sac of healthy dogs. Veterinary Ophtalmology, 18(2): 123-126. doi: 10.1111/vop.12130.

MUSCH, D.C., SUGAR, A. AND MEYER, R.F., 1983. Demographic and predisposing factors in corneal ulceration. Arch Ophthalmol, 101(10):1545-8.

OLLIVIER, F. J., 2003. Bacterial corneal diseases in dogs and cats. Clin Tech Small Anim Pract, 18(3):193198.

ORIÁ, A., GOMES JUNIOR, D., ARRAES, E., ESTRELA-LIMA, A., PINNA, M. MENESES, Í. AND MARTINS FILHO, E., 2014. Tear production, intraocular pressure and conjunctival microbiota, cytology and histology of New Zealand rabbits (Oryctolagus cuniculus). Pesquisa Veterinária Brasileira, 34(10):1024-1028, https://doi.org/10.1590/s0100-736x2014001000016

PRADO, M.R., ROCHA, M.F., BRITO, E.H., GIRÃO, M.D., MONTEIRO, A.J., TEIXEIRA, M.F. AND SIDRIM, J.J., 2005. Survey of bacterial microorganisms in the conjunctival sac of clinically normal dogs and dogs with ulcerative keratitis in Fortaleza, Ceará, Brazil. Veterinary Ophthalmology, 8(1):33-37. doi: 10.1111/j.14635224.2005.04061.x.

SANTOS L. G. F., ALMEIDA A. B. P. F., SILVA M. C., OLIVEIRA J. T., DUTRA V. AND SOUZA V. R. F., 2009. Conjunctival microbiota of healthy dogs with ophthalmic conditions Microbiota conjuntival de cães hígidos e com afecções oftálmicas. Acta Scientiae Veterinariae, 37(2): 65169. doi: 10.5216/cab.v14i4.19210. 
SAUER, P., ANDREW, S.E., LASSALINE, M. ET AL. 2003. Changes in antibiotic resistance in equine bacterial ulcerative keratitis (1991-2000): 65 horses. Veterinary Ophthalmology , 6: 309-313.

TAMARZADEH, A., ARAGUI-SOOREH, A. 2014. Bacterial flora of the conjunctiva in healthy mules. Reveu MédicineVéterinaire, 165 (11-12): 334-337.

TOLAR, E.L., HENDRIX, D.V., ROHRBACH, B.W. ET AL. 2006. Evaluation of clinical characteristics and bacterial isolates in dogs with bacterial keratitis: 97 cases (1993-2003). Journal of the American Veterinary Medical Association, 228: 80-85.
How to cite this article:

Yasmine M. Elmenshawy, Khaled M. Ali and Ahmed Samir, 2021. Current Evidence of Coryneform Bacteria on the Ocular Surface of Immunocompromised Cats. Journal of Applied Veterinary Sciences, 6 (3): $86-93$.

DOI:https://dx.doi.org/10.21608/javs.2021.81235.1087 